\title{
园林绿化设计中植物造景的作用与艺术手法
}

武文

鄂尔多斯市东胜区园林绿化事业局

DOI:10.32629/as.v2i6.1716

[摘 要] 随着中国国民经济的持续快速发展和城市化进程的加快,人们越来越重视环境问题。随着城市的发展,园林绿化的设计也在不断完善, 植物的设计和艺术技巧也更加专业。植物园林绿化在园林绿化设计中起着重要作用,园林绿化艺术技术的创新应用对于提高园林绿化效果, 更好 地满足人们的需求具有重要意义。

[关键词] 园林绿化设计; 植物造景; 艺术手法

在美化设计中, 植物美化可以美化城市景观, 减少环境污染, 满足人类 对绿色环保的需求, 并使园林景观更加独特。但是, 随着人们物质和精神水 平的不断提高, 对景观设计的要求也在不断提高。因此分析了植物园林绿 化在园林绿化设计中的作用, 并采用了最合适的植物园林绿化技术。满足 城市绿化要求, 满足人们的审美需求并改善城市品味非常重要。

\section{1 园林绿化设计中植物造景的作用}

1.1有利于改善人类居住环境

植物美化有利于城市生态的健康发展。随着城市的发展, 城市人口集 中, 城市建筑面积不断扩大, 绿地被侵占, 城市生态环境日益恶化。这些问 题不仅影响现代化产业的顺利发展, 而且直接影响着人类的居住环境。多 种树木, 多种草类, 开发花园绿地, 利用植物美化环境净化空气, 调节气候, 真空吸收有毒气体, 减少噪音, 美化城市景观, 丰富景观, 帮助改善城市的 不利环境, 促进城市生态健康发展, 实现城市可持续发展。

1.2 有利于提高人们的生活质量

在经济和城市快速发展的大背景下, 现代人的生活节奏正在加快, 生 活压力越来越大, 亚健康现象明显。因此, 为了确保人们的健康, 改善人们 的生活质量和减轻人们的紧张情绪, 有必要建造园林植物和景观, 使人们 能够与大自然亲近, 放松自己并体验生活的乐趣。要实现此目标, 需要在景 观设计中使用植物景观, 结合实际需求设计和改造景观, 并在提高花园景 观质量, 满足人们休闲娱乐需求并改善环境的基础上进行。人的生活质量。

1.3 有利于提高社会经济效益

在景观设计中植物景观的主要目的是改善环境, 净化空气, 满足人们 对高质量环境的需求以及提高城市的经济效益。城市景观设计中的植物景 观可以在很大程度上反映城市的空间感和形象, 使人们对城市有更好的印 象, 从而提高城市的声誉, 促进城市的经济发展。另外, 植物造景主要是通 过对绿色植物的利用实现的, 所以在设计过程中需要充分地发挥植物自身 吸附作用、净化作用等, 这对改善城市的环境污染, 缓解城市水土流失问题 等均具有重要作用。

\section{2 园林绿化设计中植物造景的艺术手法}

2. 1 植物美化应坚持因地制宜的原则

园林绿化美化工作应坚持科学与艺术相统一的原则, 不仅要满足植物 与生态协调发展的原则, 而且要体现出园林绿化设计的艺术性和美感, 彰 显个性之美, 和植物的美。因此, 在植物景观美化设计中, 必须坚持因地制 宜, 科学设计的原则。将植物土地与植物的特性, 特征和环境要求结合起
来。在特定的设计过程中, 有必要根据当地条件引入树木种, 通常以本地树 种为基础, 例如在沉阳适宜种植油松, 柏树, 白杨, 垂柳和杏树。

在园林绿化植物美化设计中, 有必要着眼于该地区的实际情况, 并根 据当地情况配置绿色植物。根据土壤的酸度和碱度, 日光的差异以及地形 的不同, 可以种植不同的植物。如适合种植踏柳的盐碱地, 适合种植独卷的 酸性土壤; 阳光充足的地方, 适合种植松树, 刺猬等; 阴影深色的地方, 适 合种植冷杉, 玉米等; 高处种植桉树, 丁香, 低处种植垂柳, 枫树等。此外, 在植物美化环境中, 特殊植物的特殊含义应设计成能显示不同植物给植物 带来的不同感受。使它们在植物美化方面更加独特。

2.2植物美化应遵循植物多样性定律

太多的植物美化环境不足以吸引游客的注意力, 也不能提高美化环境 的设计质量。因此, 在植物美化环境中, 必须遵循植物多样性的规律, 将花 园中的植物与生物联系起来, 以创造出更具特色的设计风格。园林绿色植 物的美化实际上是创建自然生态系统的过程。因此, 在设计中应采用科学 的植物配置方法。应使用乔木和灌木的组合来使常绿乔木与落叶乔木相匹 配。将植物配对在一起以在不同季节创建不同的植物景观。在特定的设计 过程中, 可以将树木, 灌木, 花卉, 草原, 绿篱等进行组合, 并且可以科学地 设计凉亭, 桥梁和流水等景观, 从而营造出优雅而独特的环境。还可以使用 自来水或灌木作为过渡, 以建立老年人休息区, 儿童游乐区等, 使人们可以 在不同的风景区欣赏美景。

\section{3 结束语}

总之, 在景观设计中的植物景观在改善生态环境和改善人类住区质量 方面起着非常重要的作用。在园林绿化设计中, 合理运用植物园林绿化的 方法, 遵循因地制宜的原则, 采用科学的设计技术, 展现具有深厚文化底蕴 的园林景观。如今为了解决空气污染, 噪音, 热岛效应等不利于人们健康的 “城市疾病” , 中国许多大中城市都致力于在城乡发展城市绿化。竞争为 城市创造绿色的 “生态屏障”。不断提高人们的幸福感和收获。

[参考文献]

[1]崔力文.浅析园林绿化设计中植物造景的作用与艺术手法[J].魅力 中国,2018,(39):123.

[2]陈鹏. 探究园林绿化设计中植物造景的作用与艺术手法[J]. 装饰装 修天地,2018,(15):397.

[3] 李星.探究园林绿化设计中植物造景的作用及艺术手法[J].农业与 技术,2019,39(19):142-143. 